\title{
DAMPAK RASIO KEUANGAN DAN PERTUMBUHAN PERUSAHAAN TERHADAP FINANCIAL DISTRESS MELALUI ANALISA SPRINGATE, ZMIJEWSKI, GROVER DAN ALTMAN Z-SCORE
}

\author{
Siti Fatmawati ${ }^{1}$, Endah Tri Wahyuningtyas ${ }^{2}$ \\ Prodi S1 Akuntansi. Universitas Nahdlatul Ulama Surabaya \\ sitifatmawati012.ac17@student.unusa.ac.id; endahtri@unusa.ac.id
}

\begin{abstract}
Abstrak : Financial distress merupakan perusahaan berada dalam kondisi kesulitan keuangan untuk melunasi semua kewajibannya. Salah satu faktor yang mempengaruhi kondisi financial distress adalah kegagalan dalam mengelola keuangan perusahaan. Penelitian ini bertujuan menemukan bukti empiris adanya pengaruh rasio leverage, pertumbuhan perusahaan, profitabilitas dan likuiditas terhadap financial distress serta memprediksi financial distress menggunakan 4 analisis yaitu Altman Z-score, Springate, Zmijewski dan Grover. Objek penelitian ini adalah perusahaan infastruktur, utilitas dan transportasi pada tahun 2015-2019. Penelitian ini menggunakan teknik purposive sampling dengan sampel 19 perusahaan dan 95 data perusahaan. Hasil penelitian secara bersamasama leverage, pertumbuhan perusahaan, profitabilitas, dan likuiditas dengan menggunakan 4 analisis berpengaruh terhadap financial distress. Secara parsial Rasio leverage berpengaruh negatif terhadap financial distress menggunakan model Altman Zscore. Model Grover, Springate dan Zmijewski menghasilkan bahwa rasio leverage berpengaruh positif terhadap financial distress. Rasio pertumbuhan perusahaan tidak berpengaruh terhadap financial distress menggunakan pengukuran financial distress model Altman Z-Score, Springate, Zmijewski dan Grover. Rasio profitabilitas tidak berpengaruh terhadap financial distress menggunakan model Altman Z-Score. Model Springate menunjukan bahwa rasio profitabilitas berpengaruh positif terhadap financial distress namun berpengaruh negatif melalui model Zmijewski dan Grover. Rasio likuiditas berpengaruh positif terhadap financial distress menggunakan model Altman Z-score dan Grover namun berpengaruh negatif jika melalui analisa Springate dan Zmijewski.
\end{abstract}

Kata kunci: Financial Distress, rasio keuangan, Altman Z-Score, Springate, Zmijewski, Grover.

\section{PENDAHULUAN}

Sejak pelantikan bapak Presiden banyak pelaksanaan pembangunan infastruktur yang tumbuh pesat dengan berbagai bukti diantaranya yaitu adanya peningkatan APBN pada tahun 2014 senilai 177,7 triliun dan pada tahun 2016 meningkat menjadi 317 triliun yang diambil dari (beritasatu.com). Menurut Seniman (2018) yang berpedoman pada RPJM pada tahun 2015-2019 sebanyak Rp 4.796 triliun dana yang dibutuhkan untuk memenuhi target pembangunan infastruktur. Namun, kontribusi pemerintah pusat dan daerah hanya bisa memberikan sebesar $41 \%$ untuk pembiayaan, lalu pada perusahaanperusahaan milik negara salah satunya yaitu BUMN hanya bisa memberikan kontribusi sebesar 22\%. Sehingga sebesar 37\% dari dana yang dibutuhkan harus bersumber dari sektor swasta. Faisal Basri ekonom dari universitas indonesia mengatakan bahwa Indonesia sangat membutuhkan investasi dari badan sektor swasta dalam negeri maupun luar negeri untuk membangun infrastruktur. Bila tidak maka Indonesia akan mengalami financial distress. Karena utang pemerintah dan badan usaha milik negara (BUMN) sebesar Rp 5.000 triliun. Dengan rincian utang pemerintah sebesar Rp 4.600 
triliun dan hutang badan usaha milik negara sebesar 945 triliun. Namun jika dilihat dari pertumbuhan laba sektor swasta juga mengalami financial distress.

Salah satu sektor swasta tersebut adalah sektor infastruktur, utilitas dan transportasi sektor yang padat modal dan menuntut pendanaan jangka Panjang, sehingga para investor selalu dihantui akan resiko yang terlalu tinggi saat berinvestasi pada sektor ini. setiap investor akan lebih teliti sebelum investasi melihat terlebih dahulu peluang keuntungan dan resiko yang akan didapat saat investasi. Sebab itu, untuk menarik minat investor. Maka perusahaan harus dikelola dengan sebaik mungkin. Bukti bahwa adanya financial distress diatas yaitu dengan persentase pertumbuhan laba pada sektor infrastruktur, utilitas dan transportasi periode 2015-2019.

Tabel 1. Persentase Pertumbuhan Laba sektor infrastruktur, utilitas, dan transportasi Periode 2015-2019

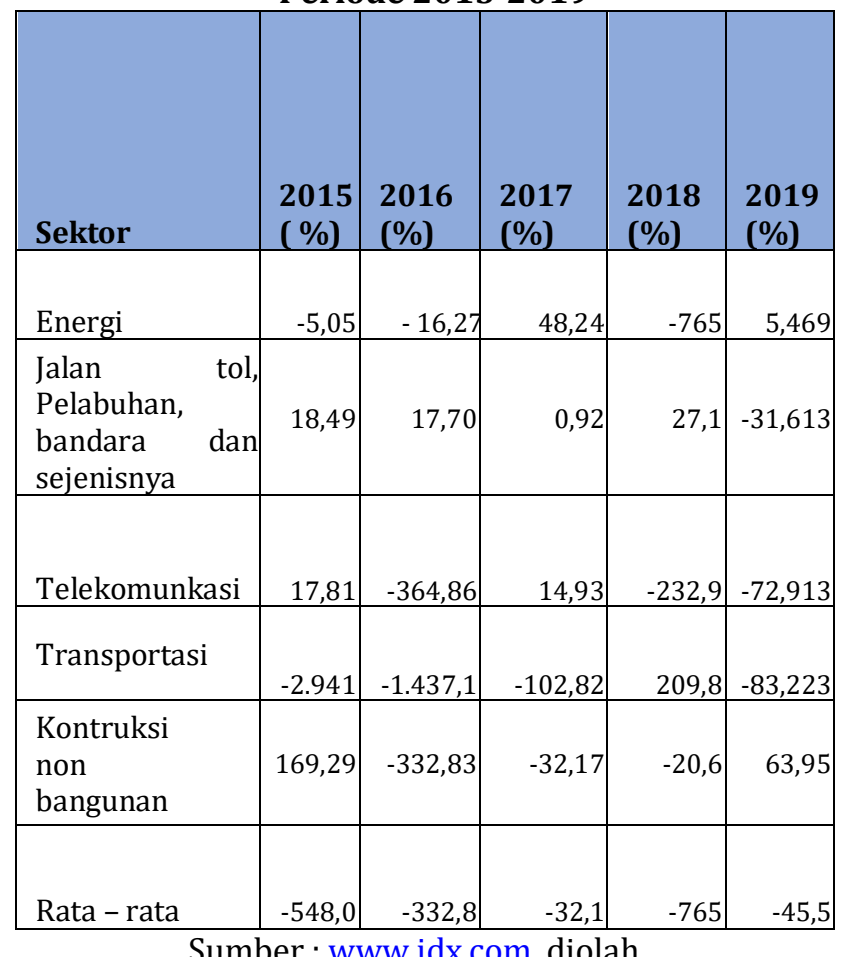

Berdasarkan Tabel 1.1 perusahaan sektor infrastruktur, utilitas dan transportasi selalu mengalami penurunan persentase penurunan laba, hampir semua perusahaan mengalami pertumbuhan laba negatif. Hal ini dapat dikatakan bahwa perusahaan infastruktur, utilitas dan transportasi tidak dalam baik atau dalam kondisi financial distress. Faktor yang dapat mempengaruhi adanya financial distress adalah faktor internal, faktor eksternal dan ekonomi. Salah satu cara yang dapat digunakan sebagai indikasi adanya kebangkrutan di perusahaan adalah rasio keuangan. Oleh karena itu pada penelitian ini menggunakan rasio leverage, pertumbuhan perusahaan, profitabilitas dan likuiditas.

Teori sinyal mendasari pada penelitian ini dan memberikan penjelasan bahwa laporan keuangan dapat memberikan sinyal positif dan sinyal negatif bagi para pemakainya. Dalam penelitian Sumeth Tuvaratragool (2013) melakukan tentang pengaturan perbandingan rasio keuangan dalam memberi sinyal adanya financial distress dengan menggunakan multi ukur yang terdiri dari skor model, emerging market, analisis tren rasio, analisis komparatif dan model logit sebagai benchmarking ukuran.

Agency theory menurut Smulowitz et al., (2019) terjadinya hubungan kontrak antara pemilik perusahaan (principal) dan manajer (agent), dimana manager diberi kekuasaan oleh pemilik untuk mengelola perusahaan dengan pedoman kontrak yang telah disetujui oleh kedua belah pihak yang disebut teori keagenan. Adanya teori keagenan tersebut di antara principal menunjuk agent sebagai pengelola dan diberi wewenang untuk mengelola. sehingga agent memiliki wewenang untuk mengambil keputusan. Jika ada kesalahan saat mengambil keputusan akan menyebabkan terjadinya financial distress.

Model financial distress perlu dikembang-kan, karena diharapkan dapat melakukan sesuatu untuk mengantisipasi kondisi yang mengarah pada kebangkrutan, seperti mengubah asset menjadi kas atau untuk memenuhi kewajiban keuangan jangka pendek perusahaan, mengalkulasi dana perusahaan yang tertanam dalam aset turnover agar revenue naik, menerbitkan saham untuk meningkatkan modal, hingga meminjam modal dari kreditor. Sehingga keadaan terburuk seperti 
kebangkrutan dapat dihindari perusahaan (Primasari, N.S. 2018).

Pada penelitian Ardian dkk., (2017) mendapatkan hasil bahwa rasio leverage yang diproksikan dengan debt ratio berpengaruh positif terhadap financial distress. Hal tersebut dapat diartikan bahwa semakin tinggi nilai leverage dapat menyebabkan adanya gejala financial distress semakin nyata karena jika suatu perusahaan mempunyai kewajiban terlalu besar mengakibatkan tingginya risiko yang dihadapi perusahaan, maka bisa diartikan akan berakibat pada perusahaan menuju kebangkrutan.

Berdasarkan teori keagenan bahwa agen yang memutuskan pendanaan dari pihak ketiga atau tidak. Jika perusahaan memiliki banyak kewajiban keuangan, maka dapat dipertanyakan apakah pihak agen sudah benar dalam mengambil sebuah keputusan dalam pengelolaan perusahaan atau memang hal tersebut dilakukan agen dengan sengaja untuk kepentingan pribadi. Berdasarkan uraian diatas maka dapat di asumsikan hipotesis sebagai berikut :

H1a : Leverage berpengaruh positif terhadap Financial distress dengan model Altman Z-Score.

$\mathrm{H} 1 \mathrm{~b}$ :Leverage berpengaruh positif terhadap Financial distress dengan model Springate.

$\mathrm{H} 1 \mathrm{c}$ :Leverage berpengaruh positif terhadap Financial distress dengan model Zmijewsk.i

H1d :Leverage berpengaruh positif terhadap Financial distress dengan model Grover.

Menurut Sopian (2016) menunjukan bahwa rasio pertumbuhan perusahaan yang diproksikan dengan sales growth berpengaruh positif terhadap financial distress. Dapat diartikan nilai pertumbuhan penjualan sangat berperan penting sebagai alat ukur seberapa mampu perusahaan dalam mempertahankan kondisi ekonomi perusahaan.

Perusahaan yang mempunyai nilai pertumbuhan tinggi dapat diidentifikasikan bahwa profit yang diperoleh perusahaan juga tinggi namun jika sebaliknya maka perusahaan tidak mampu mempertahankan posisi ekonominya dan kelangsungan operasional perusahaan sehingga perusahaan kemungkinan mengalami financial distress semakin terlihat.

Padahal rasio pertumbuhan perusahaan dalam sebuah laporan keuangan mempunyai sinyal bagi para pemangku kepentingan (investor). Investor menanamkan modal kepada perusahaan dengan tujuan mendapatkan profit, karena semakin cepat laju pertumbuhan perusahaan maka semakin banyak sinyal positif yang diberikan kepada pihak internal dan eksternal. Sinyal tersebut mengartikan bahwa kinerja perusahaan dalam kondisi baik (Susesti, D.A. \& Wahyuningtyas, E.T., 2021). Namun jika pertumbuhan perusahaan rendah investor akan mempertimbangkan hal tersebut.

Dengan uraian tersebut maka dapat dirumuskan hipotesis sebagai berikut :

H2a :Pertumbuhan Perusahaan berpengaruh positif terhadap Financial distress dengan model Altman Z-Score .

$\mathrm{H} 2 \mathrm{~b}$ :Pertumbuhan Perusahaan berpengaruh positif terhadap Financial distress dengan model Springate.

H2c :Pertumbuhan Perusahaan berpengaruh positif terhadap Financial distress dengan model Zmijewski.

H2d :Pertumbuhan Perusahaan berpengaruh positif terhadap Financial distress dengan model Grover.

Menurut penelitian Rahayu dkk. (2016) menghasilkan bahwa rasio profitabilitas berpengaruh positif terhadap financial distress. Jika suatu perusahaan mendapatkan laba yang tinggi, berarti agen berhasil menjalankan tugas dalam mengambil keputusan terhadap pengelolaan perusahaan yang baik. Rasio profitabilitas dalam penelitian ini diukur dengan ROA yang menunjukkan kemampuan dari modal yang diinvestasikan dalam keseluruhan aset untuk menghasilkan keuntungan.

Dengan adanya efektifitas dari penggunaan asset perusahaan maka perusahaan dapat memperoleh penghematan dan kecukupan dana dalam menjalankan kegiatan operasional. Kecukupan dana dikarenakan laba yang tinggi pada suatu perusahaan akan memperkecil kemungkinan 
terjadinya kondisi financial distress. Namun jika agen salah dalam mengambil keputusan dan menyebabkan rendahnya laba yang didapat maka kemungkin terjadinya financial distress semakin nyata besar. Sehingga penulis mengasumsikan uraian tersebut sebagai berikut :

H3a : Profitabilitas berpengaruh positif terhadap financial distress dengan model Altman Z-Score.

H3b : Profitabilitas berpengaruh positif terhadap financial distress dengan model Springate.

H3c : Profitabilitas berpengaruh terhadap financial distress dengan model Zmijewski.

H3d : Profitabilitas berpengaruh terhadap financial distress dengan model Grover.

Osesaga (2019) pada penelitianya menemukan hasil bahwa rasio likuiditas berpengaruh positif terhadap financial distress, Semakin besarnya likuiditas maka semakin baik kondisi keuangan perusahaan karena dapat menunjukan bahwa perusahaan dalam keadaan yang likuid sehingga financial distress semakin kecil.

Namun, tidak menuntut kemungkinan jika likuiditas yang tinggi juga dapat berdampak pada financial distress karena tingginya aset lancar berasal dari persediaan yang membutuhkan waktu lama untuk merubahnya menjadi kas sehingga perusaaan mengalami keterlambatan untuk membayar hutang jangka pendeknya. Jika suatu perusahaan mengalami masalah dalam likuiditas maka sangat memungkinkan perusahaan tersebut mulai memasuki masa kesu-litan keuangan (financial distress) dan jika kondisi kesulitan tersebut tidak cepat diatasi maka inibisa berakibat kebangkrutan usaha (Wahyuningtyas, E. T., \& Sari, D. P., 2021). Berdasarkan uraian tersebut maka dapat disimpulkan hipotesis sebagai berikut:

$\mathrm{H} 4 \mathrm{a}$ : Likuiditas berpengaruh positif terhadap Financial distress dengan model Altman Z-Score

$\mathrm{H} 4 \mathrm{~b}$ : Likuiditas berpengaruh positif terhadap Financial distress dengan model Springate

$\mathrm{H} 4 \mathrm{c}$ : Likuiditas berpengaruh positif terhadap Financial distress dengan model Zmijewski
H4d : Likuiditas berpengaruh positif terhadap Financial distress dengan model Grover

\section{METODOLOGI}

Berdasarkan dengan jenis datanya, penelitian ini dikategorikan sebagai penelitian kuantitatif deskriptif dengan sumber data sekunder yaitu annual report periode 2015 hingga 2019 dengan cara mengumpulkan data laporan keuangan yang diperoleh melalui website dari instansi/perusahaan BEI, www.idx.co.id. Sampel dalam penelitian ini menggunakan teknik purpose sampling. Metode tersebut membatasi pemilihan sampel berdasarkan kriteria tertentu

Berdasarkan kriteria sampel, maka diperoleh 95 perusahaan terindikasi mengalami financial distress. Maka jumlah sampel penelitian berjumlah 19 perusahaan. Dengan periode penelitian yang mencangkup lima tahun, yakni sejak tahun 2015 hingga tahun 2019, maka total pengamatan dalam penelitian ini berjumlah 95 laporan keuangan

Adapun variable dependen penelitian ini adalah financial distress menggunakan 4 analisa yaitu (1) Analisa Altman Z-score, Altman Z-Score dimodifikasi pada tahun 1995 ditentukan dengan cara sebagai berikut yang juga digunakan dalam penelitian (Primasari, 2018) sebagai berikut :

Z-score $=6,56 \mathrm{X} 1+3,26 \mathrm{X} 2+6,72 \mathrm{X} 3+1,05 \mathrm{X} 4$

Dimana:

X1 = Rasio Modal Kerja terhadap Total Aktiva

X2 = Rasio Laba Ditahan terhadap Total Aktiva

X3 = Rasio EBIT terhadap Total ktiva

X4 = Nilai Pasar Ekuitas terhadap Nilai Buku hutang

Cara ke dua (2) untuk menghitung financial distress menggunakan model Springate adalah sebagai berikut :

$\mathrm{S}=1,03 \mathrm{X} 1+3,07 \mathrm{X} 2+0,66 \mathrm{X} 3+0,4 \mathrm{X} 4$

$\mathrm{X} 1$ = Modal Kerja terhadap Total Aset

X2 = Laba Sebelum Bunga dan Pajak terhadap Total Aset 
X3 = Laba Bersih Sebelum Pajak terhadap Kewajiban Lancar

X4 = Penjualan Terhadap Total Aset

Cara ke tiga (3) dengan menggunakan Model Zmijewski Rumus yang digunakan dalam penelitian (Prihatini, 2013) yaitu :

$\mathrm{X}=-4,3-4,5 \mathrm{X} 1+5,7 \mathrm{X} 2-0,004 \mathrm{X} 3$

$\mathrm{X} 1$ = Laba Setelah Pajak terhadap Total Aset

X2 = Total Hutang terhadap Total Aset

$\mathrm{X} 3=$ Aset Lancar terhadap Kewajiban Lancar

Cara ke empat (4) yaitu dengan menggunakan Model Grover dalam penelitian Primasari (2018) cara menghitung dengan model Grover adalah sebagai berikut :

G-Score $=1,650 \mathrm{X} 1+3,404 \mathrm{X} 3-0,016 \mathrm{ROA}+$ 0,057

X1 = Modal Kerja terhadap Total Aset

$\mathrm{X} 2$ = Laba Sebelum Bunga dan Pajak Terhadap Total Aset

X3 = Return On Assets (ROA)

Agar data yang dikumpulkan tersebut dapat berguna maka teknik analisis data yang digunakan adalah regresi linier berganda. Agar dapat terjamin ketelitian dan keakuratan hasil perhitungan analisis regresi, maka dapat menggunakan alat bantu program spss 25. Adapun persamaan regresi linier berganda sebagai berikut.

$Y=\beta 0+\beta 1 X 1+\beta 2 X 2+\beta 3 X 3+\beta 4 X 4+\beta 5 X 5+$ $\beta 6 \mathrm{X} 6+\beta 7 \mathrm{X} 7+\mathrm{e}$

Keterangan:

$\mathrm{Y}=$ Variabel terikat

$\beta 0=$ Dugaan bagi parameter konstanta

$\beta 1=$ Koefisien regresi linier berganda variabel leverage

$\beta 2=$ Koefisien regresi linier berganda variabel pertumbuhan perusahaan

$\beta 3=$ Koefisien regresi linier berganda variabel profitabilitas.

$\beta 4=$ Koefisien regresi linier berganda variabel likuiditas.

$\mathrm{X} 1=$ Variabel leverage.

$\mathrm{X} 2$ = Variabel pertumbuhan perusahaan. $\mathrm{X} 3$

$=$ Variabel profitabilitas.

$\mathrm{X} 4=$ Variabel likuiditas.

$\mathrm{e}=$ error.

\section{HASIL DAN PEMBAHASAN}

Berikut tabel hasil uji statistic signifikansi tampak berikut :

Tabel 2. Uji T

\begin{tabular}{|c|c|c|c|c|}
\hline \multirow{2}{*}{ Variabel } & \multicolumn{4}{|c|}{ Signifkansi } \\
\cline { 2 - 5 } & $\begin{array}{l}\text { Altman Z- } \\
\text { score }\end{array}$ & Springate & Zmijewski & Grover \\
\hline DAR & $0.046-$ & $0.000-$ & $0.000+$ & $0.000+$ \\
\hline $\begin{array}{c}\text { Sales } \\
\text { Growth }\end{array}$ & $0.770+$ & $0.106+$ & $0.806+$ & $0.131+$ \\
\hline ROA & $0.390-$ & $0.000+$ & $0.000-$ & $0.000+$ \\
\hline CR & $0.000+$ & $0.000-$ & $0.000-$ & $0.000+$ \\
\hline
\end{tabular}

Sumber (SPSS, diolah)

Rasio Leverage Terhadap Financial Distress dengan Model Altman Z-Score, Springate, Zmijewski dan Grover

a. Rasio Leverage Terhadap Financial Distress dengan Model Altman Z-Score

Hasil pengujian statistik pada penelitian ini memberikan penjelasan bahwa rasio leverage yang diproksikan dengan DAR menggambarkan berpengaruh negatif terhadap financial distress karena pemakaian hutang yang besar memang sangat berisiko untuk perusahaan dikarenakan perusahaan akan dibebankan oleh bunga yang harus dibayarkan.

Namun, jika dana yang bersumber dari hutang dapat digunakan dengan baik dan efektif seperti perluasan usaha atau peningkatan promosi produk sehingga akan dapat meningkatkan kinerja perusahaan yang akan berdampak semakin kecil kemungkinan adanya financial distress pada perusahaan infastruktur, utilitas dan transportasi.

Hasil pada penelitian ini konsisten dengan penelitian Kusufiyah dan Dina (2019). Namun tidak konsisten dengan hasil penelitian dari Srikalimah (2017) menyatakan bahwa rasio leverage tidak berpengaruh terhadap financial distress.

\section{b. Rasio Leverage Terhadap Financial Distress dengan Model Springate}

Rasio leverage pada penelitian ini yang diproksikan dengan DAR menunjukan bahwa 
terdapat pengaruh negatif rasio leverage terhadap financial distress pada laporan keuangan, dikarena jika semakin tinggi tingkat pendanaan perusahaan menggunakan hutang maka semakin kecil kemungkinan perusahaan mengalami financial distress. penggunaan hutang yang besar mempunyai risiko yang sangat besar untuk perusahaan dikarenakan perusahaan akan dibebankan oleh bunga yang harus dibayarkan. Akan tetapi jika dana yang berasal dari hutang dapat dimanfaatkan dengan sebagus mungkin dan efektif seperti perluasan usaha atau peningkatan promosi produk sehingga akan dapat meningkatkan kinerja perusahaan yang akan berdampak semakin kecil kemungkinan adanya financial distress.

Penelitian ini sejalan dengan penelitian Kusufiyah dan Dina (2019), Namun, hasil penelitian tersebut tidak sejalan dengan hasil penelitian dari Srikalimah (2017) menyatakan bahwa rasio leverage tidak berpengaruh terhadap financial distress.

\section{c. Rasio Leverage Terhadap Financial Distress dengan Model Zmijewski}

Secara parsial variabel leverage berpengaruh positif terhadap financial distress karena kasmir (2012:156) apabila hasil dari pengukuran leverage tinggi maka menunjukan semakin banyaknya pendanaan dengan utang. Pada penilitian Meilinda (2012:8) juga mengungkapkan semakin besar kegiatan perusahaan yang dibiayai oleh hutang semakin besar pula kemungkinan terjadinya financial distress akibat semakin tinggi kewajiban perusahaan untuk membayar utang.

Penelitian ini sejalan dengan penelitian Utami (2009) dan Nukmaningtyas \& Worokinasih (2018) bahwa rasio leverage menggunakan model Zmijewski berpengaruh positif terhadap financial distress. . Namun tidak sejalan dengan penelitian Widhiari \& Aryani Merkusiwati (2015) dan Srikalimah (2017)

\section{d. Rasio Leverage Terhadap Financial Distress dengan Model Grover}

Pada hasil tersebut bisa katakan bahwa secara parsial variabel leverage berpengaruh positif terhadap financial distress karena Perusahaan infastruktur, utilitas dan transportasi dalam tahun 2015-2019 pembiayaanya lebih banyak menggunakan hutang, sehingga berisiko perusahaan akan mengalami kesulitan pembayaran dimasa yang akan datang akibat dari jumlah utang lebih besar dari pada aset.

Pada hasil penelitian perusahaan ini mempunyai nilai leverage yang tinggi maka resiko yang dihadapi perusahaan juga semakin besar terkait dengan biaya tetap, seperti pokok pinjaman dan biaya bunga. Oleh karena itu hutang semakin tinggi dan potensi terjadinya financial distress semakin nampak.

Kondisi tingkat leverage tinggi ini dapat berpengaruh pada peningkatan resiko yang akan dihadapi oleh kreditur. Hampir sebagian besar perusahaan yang diteliti mempunyai struktur modal yang berasal dari hutang yang tinggi. Hal inilah yang membuat kinerja perusahaan mengalami penurunan kinerja keuangan sehingga perusahaan kesulitan dalam melunasi semua kewajiban (Wahyuningtyas,E.T., 2014). Didukung oleh penelitian Utami (2009) dan Nukmaningtyas \& Worokinasih (2018) bahwa rasio leverage menggunakan model Zmijewski berpengaruh positif terhadap financial distress.

\section{Rasio Pertumbuhan Perusahaan Terhadap Financial Distress dengan Model Altman Z-Score, Springate, Zmijewski dan Grover}

Pada empat model tersebut secara parsial variabel pertumbuhan perusahaan tidak berpengaruh terhadap financial distress. Pertumbuhan perusahaaan tidak mempengaruhi financial distress, artinya bahwa pertumbuhan tidak dapat menjadi prediksi dalam mengukur financial distress perusahan. Rasio pertumbuhan perusahaan 
sebagai alat untuk mencerminkan kemampuan perusahaan dalam mempertahankan posisi ekonominya di tengah pertumbuhan ekonomi dan sektor usaha.

Rasio pertumbuhan tidak menjadi acuan utama dalam mengukur financial distress. Karena penurunan penjualan tidak secara langsung membuat perusahaan mengalami kebangkrutan, hanya mengurangi laba dan selama penurunan penjulan tidak melampaui batas maka tidak bermasalah. Pertumbuhan perusahaan tidak berpengaruh terhadap financial distress karena tinggi rendahnya pertumbuhan perusahaan yang diproksikan dengan pertumbuhan penjualan tidak dapat mempengaruhi financial distress

Penelitian ini sejalan dengan penelitian Almilia \& Kristijadi (2003) dan Liana (2003) Namun berbeda dengan penelitian Widhiari \& Aryani Merkusiwat, (2015) dan Utami (2009) mengatakan pertumbuhan perusahaan berpengaruh terhadap financial distress.

\section{Rasio Profitabilitas Terhadap Financial Distress dengan Model Altman Z-Score, Springate, Zmijewski dan Grover}

a. Rasio Profitabilitas Terhadap Financial Distress dengan Model Altman Z-Score

Secara parsial variabel profitabilitas tidak berpengaruh terhadap financial distress. Hasil dari penelitian dapat menunjukkan bahwa efektivitas dan efesiensi penggunaan aset dalam memperoleh laba. Tinggi rendahnya profitabilitas tidak berpengaruh terhadap financial distress karena saat biaya tetap mengalami kenaikan yang menyebabkan terjadinya peningkatan harga pokok penjualan yang berakibat menurunnya tingkat penjualan sehingga profitabilitas yang didapatkan perusahaan juga menurun yang berdampak pada peningkatan financial distress.
Namun jika pemanfaatan aset perusahaan di operasikan dengan baik maka terjadi peningkatan pendapatan sehingga profitabilitas naik dan financial distress semakin menurun. Sehingga dapat disimpulkan bahwa besar kecilnya profitabilitas tidak berpengaruh terhadap financial distress. Penelitian ini sejalan dengan penelitian Marfungatun (2015) yang dapat diartikan bahwa rasio profitabilitas tidak berpengaruh terhadap financial distress, Namun berbeda dengan hasil Nabawi \& Efendi (2020) dan Liana (2003).

\section{b. Rasio Profitabilitas Terhadap Financial Distress dengan Model Springate}

Secara parsial variabel profitabilitas berpengaruh positif terhadap financial distress. Nilai profitabilitas dapat berpengaruh positif terhadap financial distress karena jika laba yang didapatkan perusahaan rendah maka kemungkinan adanya financial distress semakin nyata, karena laba rendah bersumber dari tidak efektivitasnya penggunaan aset dalam memperoleh laba dan penurunan laba bersih secara berturut-turut.

Perusahaan infastruktur, utilitas dan transportasi semakin nyata financial distress karena perusahaan tidak mampu membiayai kewajiban-kewajibanya. Laba yang rendah dapat membuktikan bahwa manajemen perusahaan tidak dapat mencapai target yang telah ditetapkan. Oleh karena itu permasalahan tersebut dapat dibuat evaluasi manajemen untuk kedepanya.

Penelitian ini sejalan dengan penelitian Srikalimah (20 17) dan Christine et al., (2019) Namun berbeda dengan Nabawi \& Efendi (2020) dan Fatmawati (2017) yang menunjukan bahwa rasio profitabilitas berpengaruh negatif terhadap financial distress. 


\section{c. Rasio Profitabilitas Terhadap Financial Distress dengan Model Zmijewski}

Secara parsial variabel profitabilitas berpengaruh negatif terhadap financial distress, Hal ini dapat menunjukan bahwa semakin tinggi laba yang diperoleh perusahaan dengan melihat efektivitas dalam penggunaan aset perusahaan maka semakin rendah potensi terjadinya financial distress. Profitabilitas yang diproksikan dengan ROA memiliki nilai tinggi dapat menunjukan total aset yang digunakan untuk operasi perusahaan mampu memberikan laba bagi perusahaan. Semakin tinggi laba yang dihasilkan maka semakin tinggi nilai ROA yang dihasilkan.

Hal itu dapat diartikan bahwa perusahaan semakin efektif dalam penggunaan aset untuk menghasilkan laba sehingga adanya financial distress semakin rendah.

Penelitian ini komitmen dengan penelitian Nabawi \& Efendi (2020) dan Fatmawati (2017). Namun berbeda dengan Srikalimah (2017) dan Christine et al., (2019) bahwa rasio profitabilitas berpengaruh positif terhadap financial distress.

\section{d. Rasio Profitabilitas Terhadap Financial Distress dengan Model Grover}

Secara parsial variabel profitabilitas berpengaruh positif terhadap financial distress. Semakin rendah laba yang dihasilkan perusahaan maka semakin tinggi adanya potensi financial distress perusahaan. Nilai profitabilitas yang rendah dapat berdampak perusahaan mengalami financial distress semakin tinggi. Apabila laba negatif bersumber dari tidak efektivitasnya penggunaan aset dalam memperoleh laba dan penurunan laba bersih secara berturutturut dapat berakibat pada kondisi financial distress bertambah tinggi, Perusahaan infastruktur, utilitas dan transportasi semakin nyata financial distress
Penelitian ini sejalan dengan penelitian Srikalimah (2017) dan Christine et al., (2019) . Namun berbeda dengan Nabawi \& Efendi (2020) dan Fatmawati (2017) yang menunjukan bahwa rasio profitabilitas berpengaruh negative terhadap financial distress.

\section{Rasio Likuiditas Terhadap Financial Distress dengan Model Altman Z-Score, Springate, Zmijewski dan Grover}

\section{a. Rasio Likuiditas Terhadap Financial Distress dengan Model Altman Z-Score}

Variable likuiditas berpengaruh positif terhadap financial distress pada perusahaan infastruktur, utilitas dan transportasi yang terdaftar di BEI tahun 2015-2019 disebabkan oleh tingkat likuiditas yang tinggi akan berdampak pada terjadinya financial distress semakin tinggi. Tingkat besar nya rasio likuiditas tidak bisa menjamin pelunasan pada hutang jangka pendeknya karena sumber dari aktiva lancar bersumber dari persediaan perusahaan yang tinggi. Mengonversikan persediaan sebagai kas sangat sulit butuh waktu yang cukup lama atau berbeda-beda. Oleh karena itu pembayaran kewajiban jangka pendek mengalami keterlambatan. Sehingga akan berdampak sebagai sinyal negatif bagi para investor, mereka akan berfikir sebelum menanamkan modalnya pada berapa keuntungan dan kerugian yang akan mereka terima. Sehingga semakin tinggi likuiditas perusahaan maka semakin besar kecenderungan perusahaan mengalami kondisi financial distress.

Penelitian Fatmawati (2017) sejalan dengan hasil penelitian ini yang menyatakan bahwa rasio likuiditas berpengaruh positif terhadap financial distress. Namun berbeda dari penelitian Nukmaningtyas \& Worokinasih (2018).

\section{b. Rasio Likuiditas Terhadap Financial Distress dengan Model Springate}


Likuiditas secara signifikan berpengaruh negatif terhadap financial distress karena nilai likuiditas yang tinggi dapat menyebabkan terjadinya financial distress semakin rendah, disebabkan ketika perusahaan mempunyai nilai likuid yang semakin tinggi maka perusahaan dapat memenuhi kewajiban-kewajiban jangka pendeknya semakin baik. Perusahaan yang mempunyai nilai likuid tinggi dapat dikatakan bahwa perusahaan tersebut sangat baik karena semakin perusahaan dapat membayarkan kewajiban-kewajibanya dengan cepat.

Penelitian ini sesuai dengan penelitian Kartika \& Hasanudin (2019) sesuai dengan hasil penelitian ini yang menunjukan bahwa rasio likuiditas berpengaruh negatif terhadap financial distress. Berbeda dengan penelitian Nukmaningtyas \& Worokinasih (2018).

\section{c. Rasio Likuiditas Terhadap Financial Distress dengan Model Zmijewski}

Secara parsial variabel likuiditas berpengaruh negatif terhadap financial distress pada perusahaan infastruktur, utilitas dan transportasi yang terdaftar di BEI tahun 2015-2019. Semakin besar rasio likuiditas maka semakin kecil perusahaan mengalami financial distress. Hasil tabulasi data dari rasio likuiditas pada penelitian ini menunjukan semakin tinggi likuiditas perusahaan maka semakin rendah pula perusahaan mengalami financial distress. Perusahaan yang mempunyai nilai likuid tinggi dapat merupakan perusahaan sangat baik karena semakin perusahaan dapat membayarkan kewajiban-kewajibanya dengan tepat.

Penelitian hasil dari penelitian ini berbeda Nukmaningtyas \& Worokinasih (2018) . Namun. Kartika \& Hasanudin (2019) sesuai dengan hasil penelitian ini yang menunjukan bahwa rasio likuiditas berpengaruh negatif terhadap financial distress

\section{d. Rasio Likuiditas Terhadap Financial Distress dengan Model Grover}

Secara parsial variabel likuiditas berpengaruh positif terhadap financial distress.Rasio likuiditas berpengaruh positif terhadap financial distress disebabkan oleh tingkat likuiditas yang tinggi akan berdampak pada terjadinya financial distress semakin tinggi. Tingkat besar nya rasio likuiditas tidak bisa menjamin pelunasan pada hutang jangka pendeknya karena sumber dari aktiva lancar bersumber dari persediaan perusahaan yang tinggi. Mengonversikan persediaan sebagai kas sangat sulit butuh waktu yang cukup lama atau berbeda-beda. Oleh karena itu pembayaran kewajiban jangka pendek mengalami keterlambatan. Sehingga akan berdampak sebagai sinyal negatif bagi para investor, mereka akan berfikir sebelum menanamkan modalnya pada berapa keuntungan dan kerugian yang akan mereka terima. Sehingga semakin tinggi likuiditas perusahaan maka semakin besar kecenderungan perusahaan mengalami kondisi financial distress.

Penelitian Fatmawati (2017) sejalan dengan hasil penelitian ini yang menyatakan bahwa rasio likuiditas berpengaruh positif terhadap financial distress. Namun berbeda dari penelitian Nukmaningtyas \& Worokinasih (2018).

\section{KESIMPULAN}

Berdasarkan hasil analisis data perusahaan infastruktur, utilitas dan transportasi yang terdaftar di Bursa Efek Indonesia periode 2015 sampai dengan 2019 dapat diambil kesimpulan bahwa perusahaan cenderung lebih banyak yang mengalami pembiayaan yang banyak menggunakan hutang sehingga resiko beban yang ditanggung semakin tinggi dan adanya financial distress semakin nyata..

Oleh karena itu, keempat metode ini hanya dapat dipakai sebagai alat pendeteksi dini untuk memprediksi kondisi perusahaan 
yan mengalami financial distress agar dapat meningkatkan kinerja keuangannya dan bukan sebagai alat perhitungan yang akurat dan pasti. Sehingga salam memprediksi financial distress perusahaan sebaiknya memperhatikan rasio keuangan dan pertumbuhan perusahaan.

\section{DAFTAR PUSTAKA}

Andriawan, Nur Fadli, dan Dantje Salean, (2016). Analisis Metode Altman ZScore Sebagai Alat Prediksi Kebangkrutan dan Pengaruhnya Terhadap Harga Saham pada Perusahaan Farmasi yang Terdaftar di Bursa Efek Indonesia. Jurnal Ekonomi Akuntansi, 1.01.

Almilia, L. S., \& Kristijadi, K. (2003). Analisis rasio keuangan untuk memprediksi kondisi financial distress perusahaan manufaktur yang terdaftar di bursa efek Jakarta. Jurnal Akuntansi dan Auditing Indonesia, 7(2).

Marfungatun, F. (2017). Pengaruh Rasio Profitabilitas, Likuiditas dan Leverage Terhadap Kondisi Financial Distress Perusahaan Manufaktur yang Terdaftar di Bursa Efek Indonesia. Prodi Akuntansi UPY.

Ardian, A. V., Andini, R., \& Raharjo, K. (2017). Pengaruh Rasio Likuiditas, Rasio Leverage, Rasio Aktifitas dan Rasio Profitabilitas Terhadap Financial Distress (pada perusahaan manufaktur yang terdaftar di Bursa Efek Indonesia periode tahun 2013-2015). Journal Of Accounting, 3(3).

Christella, C., \& Osesoga, M. S. (2019). Pengaruh Leverage, Profitabilitas, Kepemilikan Institusional, Likuiditas, Dan Ukuran Perusahaan Terhadap Financial Distress. Ultimaccounting: Jurnal Ilmu Akuntansi, 11(1), 13-31.
Christine, D., Wijaya, J., Chandra, K., Pratiwi, M., Lubis, M. S., \& Nasution, I. A. (2019). Pengaruh profitabilitas, leverage, total arus kas dan ukuran perusahaan terhadap financial distress pada perusahaan property dan real estate yang terdapat di bursa efek indonesia tahun 20142017. Jesya (Jurnal Ekonomi dan Ekonomi Syariah), 2(2), 340-350.

Fatmawati, A., \& Wahidahwati, W. (2017). Faktor-Faktor yang Mempengaruhi Financial Distress (Studi Pada Perusahaan Manufaktur di BEI). Jurnal Ilmu dan Riset Akuntansi (JIRA), 6(10).

Kartika, R., \& Hasanudin, H. (2019). Analisis Pengaruh Likuiditas, Leverage, Aktivitas, Dan Profitabilitas Terhadap Financial Distress Pada Perusahaan Terbuka Sektor Infrastruktur, Utilitas, Dan Transportasi Periode 2011-2015. Oikonomia: Jurnal Manajemen, 15(1).

Marfungatun, F. (2017). Pengaruh Rasio Profitabilitas, Likuiditas dan Leverage Terhadap Kondisi Financial Distress Perusahaan Manufaktur yang Terdaftar di Bursa Efek Indonesia. Prodi Akuntansi UPY.

Nabawi, M., \& Efendi, D. (2020). Pengaruh Leverage, Profitabilitas, Aktivitas, Growth Firm Terhadap Kondisi Financial Distress. Jurnal Ilmu dan Riset Akuntansi (JIRA), 9(1).

Nukmaningtyas, F., \& Worokinasih, S. (2018). Penggunaan Rasio Profitabilitas, Likuiditas, Leverage dan Arus Kas Untuk Memprediksi Financial Distress Pada Perusahaan Sektor Aneka Industri di BEI. Jurnal Administrasi Bisnis, 61(2), 136-143.

Primasari, N. S. (2018). Analisis Altman ZScore, Grover Score, Springate, Dan 
Zmijewski Sebagai Signaling Financial Distress (Studi Empiris Industri Barang-Barang Konsumsi di Indonesia). Accounting and Management Journal,1(1). https://doi.org/10.33086/amj.v1i 1.70

Sopian, D., \& Rahayu, W. P. (2017). Pengaruh rasio keuangan dan ukuran perusahaan terhadap financial distress (studi empiris pada perusahaan food and beverage di Bursa Efek Indonesia). Competitive Jurnal Akuntansi Dan Keuangan, 1(2).

Sri Kalimah. (2017). Pengaruh Profitabilitas, Likuiditas dan Leverage Dalam Memprediksi Financial Distress (Studi Empiris Pada Perusahaan Manufaktur yang Terdaftar di BEI Periode 2009-2013). Jurnal Akuntansi \& Ekonomi FE. UN PGRI Kediri, 2(1), 43-66.

Suryani, S. (2021). Pengaruh Profitabilitas, Leverage, Sales Growth dan Ukuran Perusahaan terhadap Financial Distress. Jurnal Online Insan Akuntan, 5(2), 229-244.

https://doi.org/10.51211/joia.v5i2.1440.

Susesti, D. A., \& Wahyuningtyas , E. T. (2021). Financial Distress Determination Factors In Food And Beverages Companies In Indonesia Stock Exchanges. Kresna Social Science and Humanities Research, 1, 1-12. Retrieved from https://ksshr.kresnanusantara.co.i d/index.php/ksshr/article/view/8 $\underline{4}$

Wahyuningtyas, E. T. (2014). Pengaruh Rasio Leverage, Rasio Intensitas Modal Dan Pangsa Pasar Terhadap Kinerja Keuangan (Studi Kasus Perusahaan Tambang Di BEI). $e$ Jurnal Kewirausahaan, 2(1).
Wahyuningtyas, E. T., \& Sari, D. P. . (2021). Prediksi Financial Distress Melalui Altman Z-Score. Accounting and Management Journal, 5(1), 53-67. https://doi.org/10.33086/amj.v5i $\underline{1.2091}$

Widhiari, N. L. M. A., \& Merkusiwati, N. K. L. A. (2015). Pengaruh rasio likuiditas, leverage, operating capacity, dan sales growth terhadap financial distress. $E$ Jurnal Akuntansi Universitas Udayana, 11(2), 456-469. 